慶應義塾大学学術情報リポジトリ

Keio Associated Repository of Academic resouces

\begin{tabular}{|c|l|}
\hline Title & Structure of aconitan A, a hypoglycemic glycan of aconitum carmichaeli roots \\
\hline Sub Title & \\
\hline Author & $\begin{array}{l}\text { 友田, 正司(Tomoda, Masashi) } \\
\text { 嶋田, 和代(Shimada, Kazuyo) } \\
\text { 今野, 長八(Konno, Chohachi) } \\
\text { 村上, 美季(Murakami, Miki) } \\
\text { ヒキノ, ヒロシ(Hikino, Hiroshi) }\end{array}$ \\
\hline Publisher & 共立薬科大学 \\
\hline Publication year & 1986 \\
\hline Jtitle & $\begin{array}{l}\text { 共立薬科大学研究年報 (The annual report of the Kyoritsu College of } \\
\text { Pharmacy). No.31 (1986. ),p.35-36 }\end{array}$ \\
\hline JaLC DOI & \\
\hline Abstract & \\
\hline Notes & 抄録 \\
\hline Genre & Technical Report \\
\hline URL & https://koara.lib.keio.ac.jp/xoonips/modules/xoonips/detail.php?koara_id=AN00062898-0000003 \\
\hline
\end{tabular}

慶應義塾大学学術情報リポジトリ(KOARA)に掲載されているコンテンツの著作権は、それぞれの著作者、学会または出版社/発行者に帰属し、その権利は著作権法によって 保護されています。引用にあたっては、著作権法を遵守してご利用ください。

The copyrights of content available on the KeiO Associated Repository of Academic resources (KOARA) belong to the respective authors, academic societies, or publishers/issuers, and these rights are protected by the Japanese Copyright Act. When quoting the content, please follow the Japanese copyright act. 


$\overline{\text { 抄 } \quad \text { 銀 }}$

\title{
Structure of Aconitan A, a Hypoglycemic Glycan of Aconitum carmichaeli Roots*
}

\author{
Masashi Tomoda, Kazuyo Shimada, Chohachi Konno**, Miki Murakami**, \\ and Hiroshi HIKıno** \\ 友田正司, 嶋田和代, 今野長八,** 村上美季, ** ヒキノヒロシ**
}

We have recently isolated four glycans possessing hypoglycemic activity, aconitans A, B, C, and D, from the crude drug "bushi" (aconite), the roots of Aconitum carmichaeli Debeaux (Ranunculaceae). Structural examination of the main polysaccharide, aconitan $A$, is described in this paper.

Gel chromatography of aconitan A gave a value of 8700 for the molecular weight. Glucose was identified as the only component and nitrogen was absent. This polysaccharide was strongly dextrorotatory $\left([\alpha]_{D}+190^{\circ}\right)$ and its ${ }^{1} \mathrm{H}-\mathrm{NMR}$ spectrum exhibited an anomeric doublet $(J=3 \mathrm{~Hz})$ at $\delta 4.98$, demomstrating the D-glucose residues to be $\alpha$-linked.

Seven major signals visible in the ${ }^{13} \mathrm{C}-\mathrm{NMR}$ spectrum, at $\delta 63.2,68.3,72.2,72.9,74.1$, 76.1, and 100.4, were assignable to C-6 (free), C-6 (linked), C-4, C-5, C-2, C-3, and C-1, respectively, indicating that $\alpha$-D-glucose residues are linked at the 1 and 6 positions. The appreciable intensity of the signal for $\mathrm{C}-6$ carbon having a free hydroxyl group was indicative of branching in aconitan A. However, the branching position could not be deduced from the ${ }^{13} \mathrm{C}-\mathrm{NMR}$ spectrum at this stage, because branching was infrequent.

Aconitan A was methylated with methylsulfinyl carbanion and methyl iodide in dimethyl sulfoxide. The fully methylated product was successively hydrolyzed, reduced, and acetylated. The partially methylated glucitol acetates thus obtained were analyzed by gas-liquid chromatography-mass spectrometry. Three products were identified: 2,3,4,6-tetra- $O$-methyl-, 2,3,4-tri- $O$-methyl-, and 2,4-di- $O$-methyl-D-glucitol acetates, in the molar ratio of $1.2: 9.0: 1.0$, showing that aconitan $\mathrm{A}$ is branched through $0-3$.

When aconitan $\mathrm{A}$ was oxidized with periodate, $1.6 \mathrm{~mol}$ of periodate per mol of suger residues was consumed, with liberation of $0.8 \mathrm{~mol}$ of formic acid. The periodate-oxidized product was successively reduced, hydrolyzed, and analyzed, the yield of residual glucose being $5.8 \%$.

As it is known that the $(1 \rightarrow 6)$-glucosidic linkage is less stable to acetolysis than the $(1 \rightarrow 3)$-linkage, aconitan $\mathrm{A}$ was acetolyzed with acetic anhydride-acetic acid-sulfuric acid. The acetolysis product was deacetylated and analyzed by thin-layer chromatography and the trimethylsilylated products were examined by GLC. Both glucose and nigerose were

* 本報告は Carbohydr. Res., 147, 160-164（1986）に発表.

*** 東北大学薬学部 
detected, and determined to be in the molar ratio of $19: 1$. No component other than glucose and nigerose was found in the acetolysis product.

From these results, it may be concluded that aconitan $\mathrm{A}$ is mainly composed of $\alpha$ $(1 \rightarrow 6)$-linked D-glucopyranose residues and has branches linked, in part, through 0-3. In respect to the degree of branching, the methylation analysis and the Smith degradation show some apparent differences. The acetolysis results better support the value obtained by Smith degradation than does the methylation analysis. Aconitan $\mathrm{A}$ is concluded to be composed of $\sim 54$ glucose residues having three branching points. 